WOJCIECH ANDRASZCZYK

Uniwersytet im. Adama Mickiewicza

w Poznaniu

MARCIN GIERCZYK

Uniwersytet Śląski w Katowiach

\title{
PHYSICAL AND RELATIONAL AGGRESSION. AN INTRODUCTION TO GENDER DIFFERENTIATION
}

\begin{abstract}
Andraszczyk Wojciech, Gierczyk Marcin, Physical and Relational Aggression. An Introduction to Gender Differentiation [Agresja fizyczna i relacyjna. Wprowadzenie do różnic pomiędzy płciami]. Studia Edukacyjne nr 46, 2017, Poznań 2017, pp. 225-234. Adam Mickiewicz University Press. ISSN 1233-6688. DOI: $10.14746 /$ se.2017.46.14

This article attempts a preliminary analysis of physical and relational aggression in the context of gender. The study of literature on the subject shows that the relations between gender and the above types of aggression are complex and fit perfectly the debate between proponents of biological determinism and social constructivism. It is difficult to derive a conclusion from both the results of empirical research on this problem and theoretical considerations, which are often ideology-dependent.
\end{abstract}

Key words: physical aggression, relational aggression, gender differentiation

\section{Background}

The phenomenon of physical and relational aggression is increasingly gaining in importance in contemporary pedagogical debates. It is difficult to explicitly mention all the theoretical contexts espoused by the authors of respective texts, and moreover it is difficult to discuss the problems of research carried out in this area by Polish and foreign authors. It seems that the rapid growth in knowledge on this subject is due to increased public awareness in this area and a deepening of sensitivity - at least in Western democracies - to the violation of various types of human rights (or children's rights). We, of course, see the emergence of new forms of aggression, for example electronic stalking. However, in every century one can see an infinite number of expressions of complexes or hatred through physical and psychological aggression. 
The following text will consist of two parts. In the first, we will compare the definitions of physical and relational aggression and review existing British and American research in this area.

In the second part, we will refer to an existing awareness level about physical and relational aggression in the context of traditional conceptions of femininity and masculinity. Its essence is referring to biological determinism belief that physical violence is a genetically determined attribute of men, while relational violence is more related to the genetic disposition of women.

\section{Defining physical and relational aggression}

There are many definitions of physical ${ }^{1}$ and relational aggression ${ }^{2}$ in literature. Table 1 summarises them without leaving out the most often invoked by the precursors of these definitions, Niki R. Crick and Jennifer K Grotpeter. ${ }^{3}$

Table 1

A Comparison of Definitions and Publication Use for Relational and Physical Aggression

\begin{tabular}{|c|c|c|c|c|c|}
\hline \multirow[b]{2}{*}{ Definition } & \multicolumn{5}{|c|}{ Author } \\
\hline & $\begin{array}{l}\text { Crick and } \\
\text { Grotpeter }\end{array}$ & Tremblay & $\begin{array}{l}\text { Archer and } \\
\text { Coyne }\end{array}$ & McEvoy et al. & Merrell et al., \\
\hline $\begin{array}{l}\text { Relational } \\
\text { Aggression } \\
\text { Synonyms: } \\
\begin{array}{l}\text { Social aggres- } \\
\text { sion }\end{array} \\
\text { Covert bully- } \\
\text { ing; Indirect } \\
\text { aggression; } \\
\text { Relational } \\
\text { bullying }\end{array}$ & $\begin{array}{l}\text { Behaviors that } \\
\text { are intended } \\
\text { to significantly } \\
\text { damage an- } \\
\text { other child's } \\
\text { friendships or } \\
\text { feelings of in- } \\
\text { clusion by the } \\
\text { peer group }\end{array}$ & $\begin{array}{l}\text { It is all be- } \\
\text { haviour, with } \\
\text { the exception } \\
\text { of physical ag- } \\
\text { gression, that } \\
\text { intends to harm } \\
\text { someone }\end{array}$ & $\begin{array}{l}\text { Relational } \\
\text { aggression } \\
\text { is defined in } \\
\text { terms of its } \\
\text { endpoint, } \\
\text { which is to } \\
\text { manipulate or } \\
\text { disrupt rela- } \\
\text { tionships and }\end{array}$ & $\begin{array}{l}\text { These behav- } \\
\text { iors tend to } \\
\text { be subtle and } \\
\text { therefore, not } \\
\text { easily ob- } \\
\text { served } \\
\text { "The intimi- } \\
\text { dation is a big } \\
\text { thing... No } \\
\text { one wants to }\end{array}$ & $\begin{array}{l}\text { Relational } \\
\text { aggression } \\
\text { is defined as } \\
\text { purposefully } \\
\text { manipulating } \\
\text { and damag- } \\
\text { ing another's } \\
\text { peer relation- } \\
\text { ships }\end{array}$ \\
\hline
\end{tabular}

1 A.D. Pellegrini, J.D. Long, A longitudinal study of bullying, dominance, and victimization during the transition from primary school through secondary school, British Journal of Developmental Psychology, 2002, 20 p. 259-280; M. McEvoy et al., Assessing relational and physical aggression among preschool children: Intermethod agreement, Early Childhood Special Education, 2003, 23, p. 51-61; K.A. Dodge et al., Handbook of Child Psychology, [in:] Social, emotional, and personality development, 6th ed., Ed. N. Eisenberg, New York 2006; B. Russell, S.W. Kraus, T. Ceccherini, Student Perceptions of Aggressive Behaviors and Predictive Patterns of Perpetration and Victimization: The Role of Age and Sex, Journal of School Violence, 2010, 9(3), p. 251-270.

2 J. Archer, S.M. Coyne, An integrated review of indirect, relational, and social aggression, Personality and Social Psychology Review, 2005, 9(3), p. 212-230; M. McEvoy et al., Assessing relational, p. 51-61; K.W. Merrell, R. Buchanan, O.K. Tran, Relational aggression in children and adolescents: A review with implications for school settings, Psychology in the Schools, 2006, 42, p. 345-360.

3 N.R. Crick, J.K. Grotpeter, Relational aggression, gender, and social-psychological adjustment, Child Development, 1995, 66, p. 710-722. 


\begin{tabular}{|c|c|c|c|c|}
\hline \multirow[t]{2}{*}{$\begin{array}{l}\text { Relational } \\
\text { Aggression } \\
\text { Synonyms: } \\
\text { Social aggres- } \\
\text { sion } \\
\text { Covert bully- } \\
\text { ing; Indirect } \\
\text { aggression; } \\
\text { Relational } \\
\text { bullying }\end{array}$} & $\begin{array}{l}\text { (e.g., angrily } \\
\text { retaliating } \\
\text { against a child } \\
\text { by excluding } \\
\text { her from one's } \\
\text { play group; } \\
\text { purposefully } \\
\text { withdrawing } \\
\text { friendship or } \\
\text { acceptance in } \\
\text { order to hurt } \\
\text { or control the } \\
\text { child; spread- } \\
\text { ing rumors } \\
\text { about the child } \\
\text { so that peers } \\
\text { will reject her)* }\end{array}$ & & $\begin{array}{l}\text { friendships, } \\
\text { and its form } \\
\text { can be overt or } \\
\text { covert, but is } \\
\text { usually covert }\end{array}$ & $\begin{array}{l}\text { feel like that... } \\
\text { I think that } \\
\text { can sometimes } \\
\text { be worse, the } \\
\text { emotional } \\
\text { and that type } \\
\text { of bullying... } \\
\text { because if you } \\
\text { carry that with } \\
\text { you, it doesn't } \\
\text { give you } \\
\text { much self-con- } \\
\text { fidence" }\end{array}$ \\
\hline & $\begin{array}{l}\text { Crick and } \\
\text { Grotpeter }\end{array}$ & $\begin{array}{l}\text { Pellegrini and } \\
\text { Long }\end{array}$ & $\begin{array}{l}\text { Dodge, Coie } \\
\text { and Lynam }\end{array}$ & McEvoy et al. \\
\hline $\begin{array}{l}\text { Physical } \\
\text { Aggression } \\
\text { Synonyms: } \\
\text { Antisocial } \\
\text { behavior; } \\
\text { Assault; } \\
\text { Fighting; } \\
\text { Overt aggres- } \\
\text { sion; Physical } \\
\text { bullying; Vio- } \\
\text { lence }\end{array}$ & $\begin{array}{l}\text { Physical } \\
\text { aggression, } \\
\text { which harms } \\
\text { others via } \\
\text { physical force } \\
\text { or the threat of } \\
\text { physical force, } \\
\text { consists of such } \\
\text { behaviors as } \\
\text { hitting, push- } \\
\text { ing, } \\
\text { kicking and } \\
\text { punching }\end{array}$ & $\begin{array}{l}\text { Physical aggres- } \\
\text { sion is defined } \\
\text { as intending } \\
\text { to or actually } \\
\text { causing harm to } \\
\text { another by phys- } \\
\text { ical means. This } \\
\text { includes hitting, } \\
\text { kicking, pushing, } \\
\text { throwing objects, } \\
\text { or threatening } \\
\text { harm to another } \\
\text { person }\end{array}$ & $\begin{array}{l}\text { Physical forms } \\
\text { of aggression } \\
\text { involve direct } \\
\text { behaviours } \\
\text { (e.g., hitting, } \\
\text { kicking, or } \\
\text { punching), re- } \\
\text { lational forms } \\
\text { of aggression } \\
\text { more indirect } \\
\text { behaviours }\end{array}$ & $\begin{array}{l}\text { Aggressive } \\
\text { behavior is } \\
\text { hitting, kick- } \\
\text { ing, pushing, } \\
\text { throwing } \\
\text { things un- } \\
\text { necessarily... } \\
\text { when they } \\
\text { lose their } \\
\text { temper they'll } \\
\text { pick up things } \\
\text { and throw } \\
\text { them across } \\
\text { the room }\end{array}$ \\
\hline
\end{tabular}

* J.K. Gill, The Impact of Social Acceptance and Close Friendships on Peer and Self Perceptions of Overt and Relational Aggression Among Adolescents, University of Victoria, 2010.

We can see (Table 1 ), that there is a certain regularity which occurs in scientific discourses, characterised by a multitude of definitions of various social phenomena occurring in public space. When looking at the above descriptions, they have one feature in common, namely, a behaviour aimed at harming another human being with the use of physical or non-physical means. It is worth bearing in mind, however, that the way which we define aggression will be reflected in its measurements. ${ }^{4}$ However, as Archer and Coyne pointed out, ${ }^{5}$ researchers are often not consistent with the terminology used.

\footnotetext{
${ }^{4}$ Ibidem.

${ }^{5}$ J. Archer, S.M. Coyne, An integrated review of indirect, relational, and social aggression, Personality and Social Psychology Review, 2005, 9(3), p. 212-230.
} 


\section{Gender differences in relational and physical aggression}

Moving on to the second part of our considerations, we can state that in the case of the confrontation of physical and relational aggression with the perception of femininity and masculinity, the eternal question about the essence of male and female identity returns. The aforementioned biological reason can be quickly contrasted with the constructivist explanation of the mechanisms that create it - in the case of men and women. In this approach, the concept of "given" genetic features changes onto the category of socialisation and shaping of identity. We assume that from early childhood boys are first rewarded by parents and then by teachers in schools and peers, for activities orientated around excellent physical fitness and sports competitiveness. Their participation in fights and the use of physical strength against their peers meet more with understanding than with punishments. In turn, girls in the same age range, although perhaps to a lesser extent than in the 19th century, obtained during the socialisation such features as caring for their external image, empathy, thoughtfulness, care and avoiding open conflicts. The use of physical strength by girls is condemned and meets with various types of unambiguous sanctions. However, it would be wrong to assume that there is no fight for domination in girls' culture. It is where the division into sociometric stars and sociometric isolates occurs. However, if we follow the previous assumptions because the use of physical aggression is contrary to the dominant ethos of femininity, the methods women use to gain a position or status in the peer group (and then in the workplace) are different. That is where the relational aggression steps in. To reiterate, when explaining the identity and behaviour of women and men, there are in literature two approaches: biological essentialism and social constructivism. In the first paradigm, it is believed that femininity and masculinity stem from biology and nature. In turn, in social constructivism, there is a belief in the discursive construction of femininity and masculinity, conditioned by both socio-cultural and political-economic factors. According to this theory, the term cultural gender is used, which is more - in the context of constructivism logic - adequate to describe sex in socio-cultural and biological gender categories (concerning inherent sexual characteristics). It is also important to assume that the cultural gender not only does not necessarily coincide with the biological gender but may even be contradictory to it. ${ }^{6}$

Social constructivism considers that gender identity is socially constructed, and femininity and masculinity are standard sets of features, depending

6 E.g. K. Millet, Teoria polityki ptciowej, [in:] Nikt nie rodzi się kobieta, red. T. Hołówka, Warszawa 1982, p. 66. 
on cultural tendencies. In this approach, apart from feminine women and masculine men, there are feminine men and masculine women as well as androgynous people who combine both the feminine and masculine features. Here women can freely build their gender identity by choosing from a set of masculine and feminine traits, those that are most attractive or desirable to them.

Undoubtedly, women who use physical violence are, in a sense, breaking with the essentialist image of femininity, in which a woman is seen as delicate, empathic, and occupied with cultivating the home and raising children. The image of a physically aggressive woman denies the dichotomous division of sexes and negates the traditional feminine ideal.

It is worth adding that in a slightly different perspective a similar confrontation takes place on the ground of contemporary criminological theories. ${ }^{7}$ Two trends collide in explaining female criminality. The first, refers to the idea of biological essentialism. We are seeking the causes of criminal behaviour in deviation from the norm of femininity, which is determined by the idea of a mother and wife, a person modest and deprived of aggression or in the natural tendency of women to criminal activities. In turn, alternative theories of explaining women's criminality focus their attention on the causes and processes of a social nature that constitute them. These include taking the perspective of cultural gender into account. An example of reference to social constructivism are the views of Rita Simon, who gives up on biological determinism and espouses the belief that there are no differences between women and men in the perception of morality. The biological factors are considered irrelevant in the perspective of attempts to understand women's criminality. The essence of Rita Simon's theory is the thesis about the correlation between the increase of women's possibilities in the sphere of activities in the social space and the increase in the number of criminal acts committed by them. She writes as follows: "When more women get access to the labour market, as qualified employees with highly specific positions, the more of them commit criminal acts against property. Some women enjoy these opportunities, just like men in the past." Thus, this theory emphasises the fact that increasing women's access to positions associated with socio-economic status contributes to the increase of a specific type of crime (typical of the so-called white collar).

In turn, the paternalistic school of criminology developed in the second half of the nineteenth century with Lombroso, Ferrero, Freud, Pollack being the most representative. The central conviction regarding women's crime assumes of biological determinism, according to which women's actions and

${ }^{7}$ W. Andraszczyk, Female delinquency in selected criminological theories - gender contexts, Polish Journal of Social Rehabilitation, 2017, 14. 
thoughts are controlled by the physiological processes taking place in her body. It is believed that a disturbed hormonal balance leads to irrational behaviours, and cases to criminal acts. Women's crime is perceived here because of innate biological nature, and a woman, due to her biology, is emotionally labile, hyperactive and irrational, and her sexuality is the key to understanding the unusual nature. ${ }^{8}$

In the end, it is worth presenting the results of empirical research on physical and relational aggression in the context of femininity and masculinity Many texts devoted to this problem have been analysed accordingly. The denunciations on research relating to relational and physical aggression in the context of gender issues were sought. As indicated in Table 1 there are many definitions on that subject in literature.

Analysis has shown that distinguishing relational and physical aggression is a crucial feature when researching aggression, where gender and age are essential variables in this respect. Almost all the analysed reports showed a difference in the way men and women of different ages exhibit relational and physical aggression in interpersonal relations. The reviewed research was characterised by both methodological and thematic variations, which was presented in Scheme No. 1. The number of research samples was very different, from a small 60 respondents to a large sample, in which 5625 people

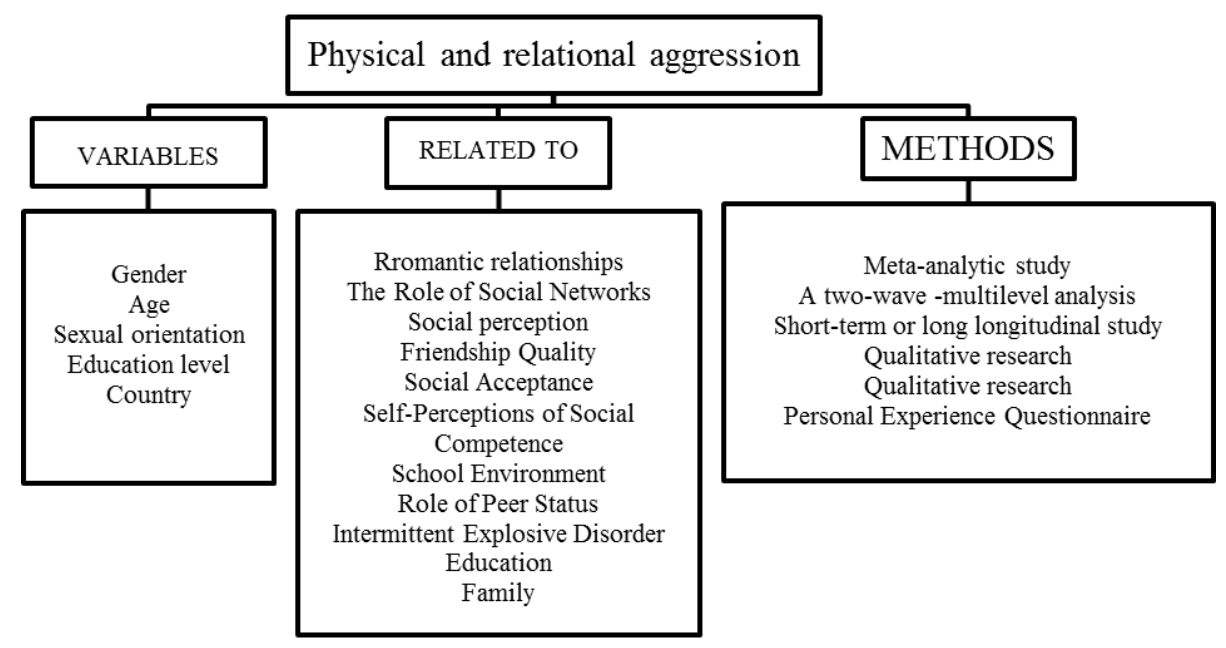

Fig. 1. Characteristics of variables, methods and thematic ranges separated from the analysed articles

${ }^{8}$ E.g. M.J. Islam, S. Banarjee, N. Khatun, Theories of Female Criminality: A criminological analysis, International Journal of Criminology and Sociological Theory, 2014, 7 (1), p. 3. 
participated in the research conducted by Caitlin Elsaesser, Deborah Gorman -Smith and David Henry. ${ }^{9}$ The respondents' age oscillated between 8 and 60 years.

The analyses carried out show that at present the problem of aggression is extensively explored by numerous researchers from around the world. They raise a wide range of issues related to the daily life of the individuals and the environment in which they operate, for example, school, ${ }^{1011}$ home, ${ }^{12}$ love relationship ${ }^{13}$ or friendship ${ }^{14}$ (Fig. 1). It can be argued that the reason for this phenomenon is the present-day brutalisation of social life.

As already mentioned, one common characteristic variable in the studies was the gender for which these explorations were conducted. Dianna Murray-Close et al. showed in their research that

gender differences in overall levels of relational aggression were not observed; however, males were most likely to engage in peer-directed proactive and reactive relational aggression whereas females were most likely to engage in romantic relational aggression. ${ }^{15}$

Susan Basow et al. also came to an interesting conclusion, saying that

despite popular conceptions that females use and are harmed by relational aggression more than males, there was no gender difference in experience with relational aggression, nor were female targets viewed as more harmed by such aggression than their male counterparts. ${ }^{16}$

${ }^{9}$ C. Elsaesser, D. Gorman-Smith, D. Henry, The Role of the School Environment in Relational Aggression and Victimization, Journal of Youth Adolescence, 2013, 42, p. 235-249.

${ }^{10} \mathrm{H}$. Rohlf, B. Krahé, R. Busching, The socializing effect of classroom aggression on the development of aggression and social rejection: A two-wave multilevel analysis, Journal of School Psychology, 2015, 58, p.57-72.

${ }_{11}$ C. Elsaesser, D. Gorman-Smith, D. Henry, The Role of the School Environment, p. 235-249.

${ }^{12}$ C.A. Swit, A. McMaugh, W.A. Warburton, Teacher and Parent Perceptions of Relational and Physical Aggression During Early Childhood, The Journal of Child and Family Studies, 2018, 27, p. 118-130.

${ }^{13}$ L. Stockdale, S. Tackett, S.M. Coyne, Sex differences in verbal aggression use in romantic relationships: a meta-analytic study and review, Journal of Aggression, Conflict and Peace Research, 2016, 5(3), p. 167-178.

14 A.M. Banny et al., Relational Benefits of Relational Aggression: Adaptive and Maladaptive Associations with Adolescent Friendship Quality, Developmental Psychology, 2011, 47(4), p. 11531166.

15 D. Murray-Close et al., Proactive, reactive, and romantic relational aggression in adulthood: Measurement, predictive validity, gender differences, and association with Intermittent Explosive Disorder, Journal of Psychiatric Research, 2010, 44. p. 393.

16 S.A. Basow et al., Perceptions of relational and physical aggression among college students: Effects of gender of perpetrator, target, and perceiver, Psychology of Women Quarterly, 2007, 31(1), p. 85. 
It is worth mentioning here the reconstructions of this problem contained in Agnieszka Gromkowska-Melosik text. She writes that

meta-analyses conducted by Eagly and Steffen of various types of research have shown that "men are more aggressive than women and these gender differences are more pronounced in the case of physical rather than psychological aggression". ${ }^{17}$

Similarly, the same author recalls the views of Kaj Björkqvist, who claims that "in the case of physical aggression" it is certainly true that men are more aggressive than women, at least in Western societies (which conversely using more of verbal aggression)" ${ }^{18}$

The above conclusions coincide with the results of qualitative and quantitative research by Angela Page and Lisa F. Smith. The authors have shown that

there was no gender difference in the perpetration of physical aggression. However, girls were more likely to perpetrate and be targets of relational aggression than were boys, but were more likely than boys to act in prosocial ways. Boys were more likely to be targets of physical aggression. ${ }^{19}$ The relational aggression however, was highly correlated for both genders. ${ }^{20}$

Agnieszka Gromkowska-Melosik also quotes the views of Anne L. Cummings, Sue Hoffman and Alan W. Lechied, who claim that

girls to a lesser extent engage in strictly physical aggressive behaviours resulted from the gender socialisation specific to this group, which limits the possibilities expressing aggression openly. Consequently, this aggression is subject to a "transference" and is expressed by seemingly less aggressive behaviours, but equally, if not more, severe for the victim. In relationships among girls, this is about ruthlessly excluding a friend from the group, spreading gossip about the victim, which causes her rejection by other people, emotional blackmail, the essence of which is "withdrawal of friendship" if the victim does not "submit". ${ }^{21}$

Agnieszka Gromkowska-Melosik also refers to the considerations of Marion K. Underwood who maintains that "girls to a lesser extent than boys

17 A. Gromkowska-Melosik, Social Constructs of Girls' Aggression. Selected Contexts and Controversies, Studia Edukacyjne, 2006, 39, p. 63.

${ }_{18} \mathrm{~K}$. Björkqvist, Sex differences in physical, verbal, and indirect aggression. A review of recent research, Sex Roles, 1994, 30, p. 178 after: A. Gromkowska-Melosik, Social Constructs of Girls' Aggression.

19 A. Page, L.F. Smith, Relational aggression and physical aggression among adolescent Cook Islands students, Issues in Educational Research, 2016, 26(1), p. 98-116.

${ }^{20}$ Ibidem.

21 A.L. Cummings, S. Hoffman, A.W. Leschied, A psychoeducational group for aggressive adolescent girls, The Journal for Specialists in Group Work, 2004, 29, 3, p. 286 after: A. Gromkowska-Melosik, Social Constructs of Girls' Aggression. 
express physical aggression, and to a greater extent - relational" .22 However, from the results of studies published in 2011, carried out among 277 students aged 0-12-20 years attending the Chilean capital of Santiago, showed that boys were more aggressive than girls, while gender differences about relational aggression did not appear. At the same time, it turned out that people of both sexes who were physically and relationally aggressive were also more popular among peers. ${ }^{23}$ Perhaps the high level of relational aggression among Chilean boys is related to the cultural specificity of this area.

\section{Conclusion}

In conclusion, we can determine that most of the research shows that physical aggression dominates among boys and relational aggression among girls, although the distribution of them is not even. It means that there are girls who show more physical aggression than many boys, and boys who are more aggressive than many girls. We are not able to answer the question about the relationship between physical aggression and its predominance among boys and the relational aggression and its predominance among girls and also determinants of biological nature or socialisation influences. This problem is worthy of further research that should be undertaken shortly.

\section{BIBLIOGRAPHY}

Andraszczyk W., Female delinquency in selected criminological theories-gender contexts, Polish Journal of Social Rehabilitation, 2017, 14.

Archer J., Coyne S.M., An integrated review of indirect, relational, and social aggression, Personality and Social Psychology Review, 2005, 9(3).

Banny A.M., Heilbron N., Ames A., Prinstein M.J., Relational Benefits of Relational Aggression: Adaptive and Maladaptive Associations with Adolescent Friendship Quality, Developmental Psychology, 2011, 47(4).

Basow S.A., Cahill K.F., Phelan J.E., Longshore K., McGillicuddy-DeLisi A., Perceptions of relational and physical aggression among college students: Effects of gender of perpetrator, target, and perceiver, Psychology of Women Quarterly, 2007 31(1).

Björkqvist K., Sex differences in physical, verbal, and indirect aggression. A review of recent research, SexRoles, 1994, 30.

Crick N.R., Grotpeter J.K., Relational aggression, gender, and social-psychological adjustment, Child Development, 1995, 66.

${ }_{22}$ M.K. Underwood, Social aggression among girls, New York 2003, p. 234, after: A. Gromkowska-Melosik, Social Constructs of Girls' Aggression.

23 Dijkstra, Berger, Linderberg, Do Physical and Relational..., https://www.stats.ox.ac. uk/ snijders/siena/DijkstraBergerLindenberg2011.pdf s. 6. 
Dijkstra, Berger, Linderberg, Do Physical and Relational...., https://www.stats.ox.ac.uk/ snijders/siena/DijkstraBergerLindenberg2011.pdf s. 6.

Dodge M., Where are all the women in white-collar crime? [in:] Routledge International Handbook of Crime and Gender Studies, Eds. C.M. Renzetti, S.L. Miller, A.R. Gover, Routledge, New York 2013.

Dodge K.A., Coie J.D, Lynam D., Damon W., Handbook of Child Psychology, [in:] Social, emotional, and personality development, 6th ed., Ed. N. Eisenberg, Wiley, New York 2006.

Elsaesser C., Gorman-Smith D., Henry D., The Role of the School Environment in Relational Aggression and Victimization, Journal of Youth Adolescence, 2013, 42.

Gill J.K, The Impact of Social Acceptance and Close Friendships on Peer and Self Perceptions of Overt and Relational Aggression Among Adolescents, University of Victoria, 2010

Gromkowska-Melosik A., Social Constructs of Girls' Aggression. Selected Contexts and Controversies, Studia Edukacyjne, 2006, 39.

Islam M.J., Banarjee S., Khatun N., Theories of Female Criminality: A criminological analysis, International Journal of Criminology and Sociological Theory, 2014, 7, 1.

McEvoy M., Estrem T., Rodriguez M., Olson M., Assessing relational and physical aggression among preschool children: Intermethod agreement, Topics in Early Childhood Special Education, 2003, 23.

Merrell K.W., Buchanan R., Tran O.K., Relational aggression in children and adolescents: A review with implications for school settings, Psychology in the Schools, 2006, 42.

Millet K., Teoria polityki ptciowej, [in:] Nikt nie rodzi się kobieta, red. T. Hołówka, Warszawa 1982.

Murray-Close D., Ostrov J.M., Nelson D.A. Crick N.R., Coccaro E.F., Proactive, reactive, and romantic relational aggression in adulthood: Measurement, predictive validity, gender differences, and association with Intermittent Explosive Disorder, Journal of Psychiatric Research $2010,44$.

Page A., Smith L.F., Relational aggression and physical aggression among adolescent Cook Islands students, Issues in Educational Research, 2016, 26(1).

Pellegrini A.D., Long J.D., A longitudinal study of bullying, dominance, and victimization during the transition from primary school through secondary school, British Journal of Developmental Psychology, 2002, 20.

Rohlf H., Krahé B., Busching R., The socializing effect of classroom aggression on the development of aggression and social rejection: A two-wave multilevel analysis, Journal of School Psychology, 2015, 58.

Russell B., Kraus S.W., Ceccherini T., Student Perceptions of Aggressive Behaviors and Predictive Patterns of Perpetration and Victimization: The Role of Age and Sex, Journal of School Violence, 2010, 9(3).

Stockdale L., Tackett S., Coyne S.M., Sex differences in verbal aggression use in romantic relationships: a meta analytic study and review, Journal of Aggression, Conflict and Peace Research, 2016, 5(3).

Swit C.A., McMaugh A., Warburton W.A., Teacher and Parent Perceptions of Relational and Physical Aggression During Early Childhood, The Journal of Child and Family Studies, 2018, 27. 